\title{
Organocatalytic Transfer Hydrogenation of Cyclic Enones
}

\author{
Jamison B. Tuttle, Stéphane G. Ouellet and David W. C. MacMillan* \\ Division of Chemistry and Chemical Engineering, California Institute of Technology, Pasadena, \\ California 91125
}

\section{Supporting Information}

General Information. Commercial reagents were purified prior to use following the guidelines of Perrin and Armarego. ${ }^{1}$ Non-aqueous reagents were transferred under nitrogen via syringe or cannula and purified according to the method of Grubbs. ${ }^{2}$ Organic solutions were concentrated under reduced pressure on a Büchi rotary evaporator. Chromatographic purification of products was accomplished using forced-flow chromatography on ICN 60 32-64 mesh silica gel and Iatrobeads $^{\circledR}$ according to the method of Still. ${ }^{3}$ Thin-layer chromatography (TLC) was performed on EM Reagents $0.25 \mathrm{~mm}$ silica gel $60-\mathrm{F}$ plates. Chromatograms were visualized by fluorescence quenching or by staining using either potassium permanganate or $p$-anisaldehyde stain.

${ }^{1} \mathrm{H}$ and ${ }^{13} \mathrm{C}$ NMR spectra were recorded on a Varian Mercury 300 Spectrometer, and are internally referenced to residual solvent signals. Data for ${ }^{1} \mathrm{H}$ NMR are reported as follows: chemical shift $(\delta \mathrm{ppm})$, multiplicity $(\mathrm{s}=$ singlet, $\mathrm{d}=$ doublet, $\mathrm{t}=$ triplet, $\mathrm{q}=$ quartet, $\mathrm{m}=$ multiplet), integration, coupling constant $(\mathrm{Hz})$ and assignment. Data for ${ }^{13} \mathrm{C}$ NMR are reported in terms of chemical shift. IR spectra were recorded on a Perkin Elmer Paragon 1000 spectrometer and are reported in terms of frequency of absorption $\left(\mathrm{cm}^{-1}\right)$. Mass spectra were obtained from the Caltech Mass Spectrometry facility by electron ionization, chemical ionization, or fast atom/ion bombardment techniques. Gas liquid chromatography (GLC) was performed on Hewlett-Packard 6850 and 6890 Series gas chromatographs equipped with a splitmode capillary injection system and flame ionization detectors using a Bodman Chiraldex $\beta$-DM $(30 \mathrm{~m} \times 0.25 \mathrm{~mm})$, a Bodman Chiraldex $\Gamma$-TA $(30 \mathrm{~m} \times 0.25 \mathrm{~mm})$ or a Hydrodex-B-TBDAc $(50$

\footnotetext{
${ }^{1}$ Perrin, D. D.; Armarego, W. L. F. Purification of Laboratory Chemicals; $3^{\text {rd }}$ ed., Pergamon Press, Oxford, 1988.

${ }^{2}$ Pangborn, A. B.; Giardello, M. A.; Grubbs, R. H.; Rosen, R. K.; Timmers, F. J. Organometallics 1996, $15,1518$.

${ }^{3}$ Still, W. C.; Kahn, M.; Mitra, A. J. J. Org. Chem. 1978, 43, 2923.
} 
$\mathrm{m} \times 0.25 \mathrm{~mm}$ ) column as noted. Optical rotations were measured on a Jasco P-1010 polarimeter, and $[\alpha]_{\mathrm{D}}$ values are reported in $10^{-1} \mathrm{dg} \mathrm{cm}^{2} \mathrm{~g}^{-1}$; concentration (c) is in $\mathrm{g} / 100 \mathrm{ml}$.

\section{Preparation of the starting materials}

These $\alpha, \beta$-unsaturated cyclic enones are commercially available from Aldrich: 3-methyl-2cyclopenten-1-one and isophorone (3,5,5-trimethylcyclohex-2-enone). The following $\alpha, \beta$ unsaturated cyclic enones have already been described in the literature: 3-hexylcyclopent-2enone, 3-cyclohexylcyclopent-2-enone, ${ }^{4} 3$-tert-butylcyclopent-2-enone, ${ }^{5} 3$-phenylcyclopent-2enone, ${ }^{6} 3$-benzylcyclopent-2-enone, ${ }^{7} 3$-(benzyloxymethyl)cyclopent-2-enone, ${ }^{8}$ methyl 3oxocyclopent-1-enecarboxylate ${ }^{16}, 3$-acetylcyclopent-2-enone, ${ }^{9}$ 3-butylcyclohex-2-enone ${ }^{10}, 3$ cyclohexylcyclohex-2-one ${ }^{11}$

\section{General procedure for the preparation of starting materials:}
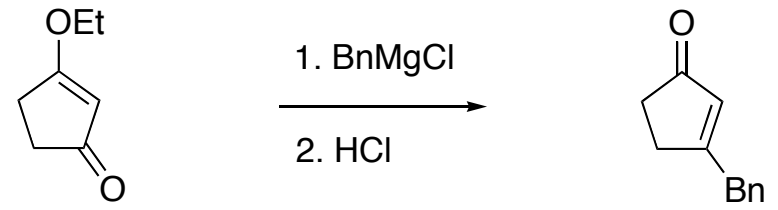

3-benzylcyclopent-2-enone: To a $-78{ }^{\circ} \mathrm{C}$ solution of benzyl magnesium chloride $(14.3 \mathrm{~mL}, 28.5$ mmol, 1.2 eq., $2 \mathrm{M}$ solution in THF) in ether (50 mL) was slowly added 3-ethoxycyclopent-2enone (2.84 mL, $23.8 \mathrm{mmol}, 1$ eq.). The reaction mixture was warmed up to $-30{ }^{\circ} \mathrm{C}$ over 1 hour followed by addition of a $1 \mathrm{M}$ solution of $\mathrm{HCl}$ until the $\mathrm{pH}$ was adjusted to 1 as indicated by litmus paper. The solution was warmed up to room temperature and the layers were separated. The aqueous phase was extracted with $40 \mathrm{~mL}$ of $\mathrm{Et}_{2} \mathrm{O}(3 \times)$ and the combined organic layers were washed with $100 \mathrm{~mL}$ of brine (1x), dried over anhydrous $\mathrm{MgSO}_{4}$ and concentrated in vacuo. The residual oil was purified by flash chromatography $(25 \%$ EtOAc/hexanes) to afford the title compound as a colorless oil (3.1 g, 76\% yield).

\footnotetext{
${ }^{4}$ Collins, S.; Hong, Y.; Mataoka, M.; Nguyen, T. J. Org. Chem. 1990, 55, 3395.

${ }^{5}$ Ponaras, A. A.; Zaim, O.; Pazo, Y.; Ohannesian, L. J. Org. Chem. 1988, 53, 1110. and Garbisch, E. W., Jr.; Sprecher, R. F. J. Am. Chem. Soc. 1969, 91, 6785.

${ }^{6}$ Jurkauskas, V.; Sadigni, J. P.; Buchwald, S. L. Org. Lett. 2003, $5,2417$.

${ }^{7}$ Moritani, Y.; Appella, D. H.; Jurkauskas, V.; Buchwald, S. L. J. Am. Chem. Soc. 2000, 122, 6797.

${ }^{8}$ Dauben, W. G.; Warshawsky, A. M. J. Org. Chem. 1990, 55, 3075.

${ }^{9}$ Yu, J.-Q.; Corey, E. J. J. Am. Chem. Soc. 2003, 125, 3232. And Catino, A. J.; Forslund, R. E.; Doyle, M. P. J. Am. Chem. Soc. 2004, 126, 13622.

${ }^{10}$ Mudryk, B.; Cohen, T. J. Am. Chem. Soc. 1993, 115, 3854.
} 
(Z)-1-butylcyclohept-2-enol: To a clear solution of 2-cyclohepten-1-one (5 g, $45.5 \mathrm{mmol})$ in ether $(50 \mathrm{~mL})$, cooled to $0{ }^{\circ} \mathrm{C}$, was added $n$-BuLi $(2.0 \mathrm{M}$ in hexanes, $25 \mathrm{~mL}, 50.0 \mathrm{mmol})$ dropwise to produce an opaque yellow solution. The reaction stirred for $2 \mathrm{~h}$ at $0{ }^{\circ} \mathrm{C}$ and then warmed to room temperature. After $1 \mathrm{~h}$, the reaction was complete as determined by TLC, and quenched in $50 \mathrm{~mL} \mathrm{NH}_{4} \mathrm{Cl}$. The organic layer was separated and the aqueous layer was extracted with $50 \mathrm{~mL}$ of $\mathrm{Et}_{2} \mathrm{O}(3 \times)$. The combined organic layers were dried over $\mathrm{Na}_{2} \mathrm{SO}_{4}$, filtered and concentrated in vacuo. The resulting residue was purified by flash chromatography (10\% $\mathrm{Et}_{2} \mathrm{O}$ /pentane) to afford the title compound as a light yellow oil (2 g, 26\% yield). IR (film) 3377, 3015, 2930, 2860, 1456, 1378, 1335, 1223, 1121, 1103, 1043, $997 \mathrm{~cm}^{-1}$; ${ }^{1} \mathrm{H}$ NMR (300 MHz, $\left.\mathrm{CDCl}_{3}\right) \delta 5.69(\mathrm{dt}, 1 \mathrm{H}, \mathrm{J}=11.9,5.6 \mathrm{~Hz}, \mathrm{CCH}=\mathrm{CH}), 5.59(\mathrm{~d}, 1 \mathrm{H}, \mathrm{J}=11.9 \mathrm{~Hz}, \mathrm{CCH}=\mathrm{CH}), 2.17-$ $2.09(\mathrm{~m}, 2 \mathrm{H}), 1.84-1.45(\mathrm{~m}, 9 \mathrm{H}), 1.38-1.27(\mathrm{~m}, 4 \mathrm{H}), 0.93-0.88(\mathrm{~m}, 3 \mathrm{H}) ;{ }^{13} \mathrm{C}$ NMR $(75 \mathrm{MHz}$, $\left.\mathrm{CDCl}_{3}\right) \delta 139.1,130.0,76.1,41.1,38.5,27.6,27.5,25.6,24.1,23.2,14.1$; HRMS $\left(\mathrm{EI}^{+}\right)$exact mass calculated for $[\mathrm{M}]^{+}\left(\mathrm{C}_{11} \mathrm{H}_{20} \mathrm{O}\right)$ requires $m / z$ 168.1514, found $m / z$ 168.1516.

(Z)-3-butylcyclohept-2-enone: To a solution of (Z)-1-butylcyclohept-2-enol (2 g, $11.9 \mathrm{mmol})$ dissolved in dichloromethane $(60 \mathrm{~mL})$ was added pyridine chlorochromate on basic alumina (20 wt.\%, $25.7 \mathrm{~g}, 23.8 \mathrm{mmol})$. The resulting reddish solution was stirred at room temperature for $2 \mathrm{~h}$ until determined to be complete by TLC. The mixture was diluted in $100 \mathrm{~mL} \mathrm{Et}_{2} \mathrm{O}$ and stirred for $1 \mathrm{~h}$ after which it was poured over filter paper that was subsequently washed with the $\mathrm{Et}_{2} \mathrm{O}$. The filtrate was partially concentrated $(30 \mathrm{~mL})$ and passed through a Florisil column with $\mathrm{Et}_{2} \mathrm{O}$ (100 mL). The resulting colorless solution was concentrated and purified by flash chromatography $\left(5 \% \mathrm{Et}_{2} \mathrm{O} /\right.$ Pentane) to provide a colorless oil (920 mg, 47\% yield). IR (film) 2933, 2864, 1662, 1458, 1421, 1375, 1344, 1322, 1267, 1201, 1124, 1103, 1048, 937, 875, 855 $\mathrm{cm}^{-1}$; ${ }^{1} \mathrm{H}$ NMR (300 MHz, $\mathrm{CDCl}_{3}$ ) $\delta 5.89$ (s, 1H, COCH), $2.58-2.53\left(\mathrm{~m}, 2 \mathrm{H}, \mathrm{COCH}_{2}\right), 2.41-$ $2.38(\mathrm{~m}, 2 \mathrm{H}, \mathrm{HC}=\mathrm{CCH}), 2.18\left(\mathrm{t}, 2 \mathrm{H}, \mathrm{J}=6.91 \mathrm{~Hz}, \mathrm{HC}=\mathrm{CCH}_{2}\left(\mathrm{CH}_{2}\right)_{2} \mathrm{CH}_{3}\right), 1.80-1.74(\mathrm{~m}, 2 \mathrm{H}$, $\left.\mathrm{COCH}_{2} \mathrm{CH}_{2}\right), 1.50-1.40\left(\mathrm{~m}, 2 \mathrm{H}, \mathrm{HC}=\mathrm{CCH}_{2} \mathrm{CH}_{2}\right), 1.38-1.25\left(\mathrm{~m}, 2 \mathrm{H}, \mathrm{HC}=\mathrm{C}\left(\mathrm{CH}_{2}\right)_{2} \mathrm{CH}_{2} \mathrm{CH}_{3}\right)$, $0.90\left(\mathrm{t}, 3 \mathrm{H}, \mathrm{J}=7.18 \mathrm{~Hz}, \mathrm{CH}_{2} \mathrm{CH}_{3}\right) ;{ }^{13} \mathrm{C} \mathrm{NMR}\left(75 \mathrm{MHz}, \mathrm{CDCl}_{3}\right) \delta 204.4,162.4,128.2,42.1,40.8$, 32.5, 29.7, 25.1, 22.4, 21.2, 13.9; HRMS $\left(\mathrm{EI}^{+}\right)$exact mass calculated for $[\mathrm{M}]^{+}\left(\mathrm{C}_{11} \mathrm{H}_{18} \mathrm{O}\right)$ requires $\mathrm{m} / \mathrm{z}$ 166.1358, found $\mathrm{m} / \mathrm{z}, 166.1359$.

${ }^{11}$ Snider, B. B.; Rodini, D. J.; van Straten, J. J. Am. Chem. Soc. 1980, 102, 5872. 


\section{General Procedure for the enantioselective hydrogenation of cyclic enones:}

To a solution of 3-substituted-cyclopent-2-enone $(1 \mathrm{mmol})$ dissolved in $0.5 \mathrm{~mL}$ of $\mathrm{Et}_{2} \mathrm{O}(0.5 \mathrm{M})$, cooled to $4{ }^{\circ} \mathrm{C}$ using an ice bath, was added (2S,5S)-5-benzyl-3-methyl-2-(5-methylfuran-2yl)imidazolidin-4-one (54 mg, $0.2 \mathrm{mmol}, 0.2$ eq.), followed by $t$-Butyl Hantzsch ester (340 mg, $1.1 \mathrm{mmol}, 1.1$ eq.), then trichloroacetic acid (33 mg, $0.2 \mathrm{mmol}, 0.2$ eq.). The resulting yellow suspension was stirred at $4{ }^{\circ} \mathrm{C}$ until the reaction was judged to be complete by TLC. The reaction mixture was passed through a short pad of silica gel and eluted with $\mathrm{Et}_{2} \mathrm{O}$. The resulting solution was concentrated in vacuo and purified by flash chromatography (solvent noted) to provide the title compound. Where noted, the pyridine by-product was removed by washing the final compound with $5 \mathrm{~mL} 6 \mathrm{M} \mathrm{HCl}(3 \times), 5 \mathrm{ml} \mathrm{H} 2 \mathrm{O}(1 \times)$ and $5 \mathrm{ml}$ sat. $\mathrm{NaHCO}_{3}(1 \times)$ to provide the title compound. These conditions were used as an alternative to repeating the column chromatography.

(R)-3-methylcyclopentanone: Prepared according to the general procedure from 3methylcyclopent-2-enone $(100 \mathrm{mg}, 1.04 \mathrm{mmol})$ for $8.5 \mathrm{~h}$ to provide the title compound $(72 \%$ conversion, 95\% ee). Conversion was determined via GLC analysis by comparison with an internal standard $(\mathrm{BnOMe})$. The physical data were identical in all respects to those of the commercially available $(R)$-3-methylcyclopentanone. The enantiomeric ratio was determined by GLC using a Bodman Chiraldex $\Gamma$-TA $(30 \mathrm{~m} \times 0.25 \mathrm{~mm})$ column $\left(100{ }^{\circ} \mathrm{C}\right.$ isotherm, $1 \mathrm{~mL} / \mathrm{min}$.); $(S)$ isomer $t_{\mathrm{r}}=25.1 \mathrm{~min}$. and $(R)$ isomer $t_{\mathrm{r}}=25.8 \mathrm{~min}$.

(R)-3-cyclohexylcyclopentanone: Prepared according to the general procedure from 3cyclohexylcyclopent-2-enone $(200 \mathrm{mg}, 1.31 \mathrm{mmol})$ for $11 \mathrm{~h}$ to provide the title compound as a yellow oil (165 mg, 82\% yield, 93\% ee) after purification by flash chromatography on Iatrobeads $^{\circledR}\left(15-20 \% \mathrm{Et}_{2} \mathrm{O} /\right.$ pentane $)$ and a final acid wash. The physical data were identical in all respects to those previously reported. ${ }^{12}$ The enantiomeric ratio was determined by GLC using a Hydrodex-B-TBDAc $(50 \mathrm{~m} \times 0.25 \mathrm{~mm})$ column $\left(105^{\circ} \mathrm{C}\right.$ isotherm, $1 \mathrm{~mL} / \mathrm{min}$. $)$; $(S)$ isomer $t_{\mathrm{r}}=$ $127.7 \mathrm{~min}$. and $(R)$ isomer $t_{\mathrm{r}}=127.9 \mathrm{~min} .[\alpha]_{D}^{22}=+8.6^{\circ}\left(\mathrm{c}=1.00, \mathrm{CHCl}_{3}\right)$.

\footnotetext{
${ }^{12}$ Jones, P.; Reddy, C. K.; Knochel, P. Tetrahedron 1998, 54, 1471. (racemic product, no optical rotation)
} 
(R)-3-tert-butylcyclopentanone: Prepared according to the general procedure from 3-tertbutylcyclopent-2-enone $(100 \mathrm{mg}, 0.723 \mathrm{mmol})$ for $5.5 \mathrm{~h}$ to provide the title compound as a colorless oil ( $81 \%$ conversion, $96 \%$ ee). Conversion was determined via GLC analysis by comparison with an internal standard (BnOMe). The physical data were identical in all respects to those previously reported. ${ }^{13}$ The enantiomeric ratio was determined by GLC using a Bodman Chiraldex $\Gamma$-TA $(30 \mathrm{~m} \times 0.25 \mathrm{~mm})$ column $\left(90{ }^{\circ} \mathrm{C}\right.$ isotherm, $1 \mathrm{~mL} / \mathrm{min}$.); $(S)$ isomer $t_{\mathrm{r}}=14.4$ min. and $(R)$ isomer $t_{\mathrm{r}}=15.0 \mathrm{~min} .[\alpha]_{D}^{22}=+150.3^{\circ}\left(\mathrm{c}=1.00, \mathrm{CHCl}_{3}\right)$.

General procedure B provided the title compound (81\% conversion, $96 \%$ ee) after 5.5 hours.

(R)-3-benzylcyclopentanone: Prepared according to the general procedure from 3benzylcyclopent-2-enone (200 mg, $1.16 \mathrm{mmol}$ ) for $11 \mathrm{~h}$. After the reaction mixture was passed though a short pad of silica gel, the resulting mixture was poured into $5 \mathrm{~mL}$ of a $10 \% \mathrm{HCl}$ solution and diluted with $5 \mathrm{~mL}$ of $\mathrm{Et}_{2} \mathrm{O}$. The layers were separated, then the organic layer was washed with $5 \mathrm{~mL}$ of a $10 \% \mathrm{HCl}$ solution $(4 \times)$ and with $5 \mathrm{~mL}$ of water $(1 \times)$. The resulting solution was dried over $\mathrm{MgSO}_{4}$ and concentrated in vacuo to provide the title compound as a colorless oil (157 mg, 78\% yield, $90 \%$ ee) after purification by flash chromatography on Iatrobeads $^{\circledR}\left(2 \% \mathrm{Et}_{2} \mathrm{O} /\right.$ benzene $)$ and a final acid wash. The physical data were identical in all respects to those previously reported. ${ }^{14}$ The enantiomeric ratio was determined by GLC using a Hydrodex-B-TBDAc $(50 \mathrm{~m} \times 0.25 \mathrm{~mm})$ column $\left(145^{\circ} \mathrm{C}\right.$ isotherm, $\left.1 \mathrm{~mL} / \mathrm{min}.\right) ;(S)$ isomer $t_{\mathrm{r}}=$ $91.5 \mathrm{~min}$. and $(R)$ isomer $t_{\mathrm{r}}=90.1 \mathrm{~min} .[\alpha]_{D}^{22}=+83.9^{\circ}\left(\mathrm{c}=1.00, \mathrm{CHCl}_{3}\right)$.

(R)-3-(benzyloxymethyl)cyclopentanone: Prepared according to the general procedure from 3(benzyloxymethyl)cyclopent-2-enone $(200 \mathrm{mg}, 1.06 \mathrm{mmol})$ for $13 \mathrm{~h}$. After the reaction mixture was passed though a short pad of silica gel, the resulting solution was poured into $5 \mathrm{~mL}$ of a $10 \%$ $\mathrm{HCl}$ solution and diluted with $5 \mathrm{~mL}$ of $\mathrm{Et}_{2} \mathrm{O}$. The layers were separated, then the organic layer was washed with $5 \mathrm{~mL}$ of a $10 \% \mathrm{HCl}$ solution (4x) and with $5 \mathrm{~mL}$ of water (1x). The resulting solution was dried over $\mathrm{MgSO}_{4}$ and concentrated in vacuo to provide the title compound as a colorless oil (180 mg, 89\% yield, 91\% ee) after purification by flash chromatography on silica

\footnotetext{
${ }^{13}$ Ahlbrecht, H.; Weber, P. Synthesis 1992, 1019. (racemic product, no optical rotation)
} 
gel $\left(10 \% \mathrm{Et}_{2} \mathrm{O} /\right.$ pentane). The enantiomeric ratio was determined by GLC using a Hydrodex-BTBDAc $(50 \mathrm{~m} \times 0.25 \mathrm{~mm})$ column $\left(150{ }^{\circ} \mathrm{C}\right.$ isotherm, $\left.1 \mathrm{~mL} / \mathrm{min}.\right) ;(S)$ isomer $t_{\mathrm{r}}=151.2 \mathrm{~min}$. and $(R)$ isomer $t_{\mathrm{r}}=153.2 \mathrm{~min}$. IR (film) 3030, 2860, 1740, 1404, $1100 \mathrm{~cm}^{-1} ;{ }^{1} \mathrm{H} \mathrm{NMR} \mathrm{(300} \mathrm{MHz,}$ $\left.\mathrm{CDCl}_{3}\right) \delta 7.42-7.28\left(\mathrm{~m}, 5 \mathrm{H}, \mathrm{ArH}_{5}\right), 4.55\left(\mathrm{~s}, 2 \mathrm{H}, \mathrm{CH}_{2} \mathrm{Ph}\right), 3.51\left(\mathrm{~d}, 2 \mathrm{H}, J=6.3 \mathrm{~Hz}, \mathrm{CHCH}_{2} \mathrm{O}\right)$, $2.61-2.49(\mathrm{~m}, 1 \mathrm{H}), 2.44-2.25(\mathrm{~m}, 2 \mathrm{H}), 2.23-2.01(\mathrm{~m}, 3 \mathrm{H}), 1.84-1.71(\mathrm{~m}, 1 \mathrm{H}) ;{ }^{13} \mathrm{C} \mathrm{NMR}$ $\left(75 \mathrm{MHz}, \mathrm{CDCl}_{3}\right) \delta 219.2,138.1,128.3,127.4,126.8,73.2,73.0,41.9,37.8,36.7,26.0$; HRMS $\left(\mathrm{EI}^{+}\right)$exact mass calculated for $[\mathrm{M}]^{+}\left(\mathrm{C}_{13} \mathrm{H}_{16} \mathrm{O}_{2}\right)$ requires $\mathrm{m} / \mathrm{z}$ 204.1150, found $\mathrm{m} / \mathrm{z}$ 204.1144; $[\alpha]_{D}^{22}=+31.2^{\circ}\left(\mathrm{c}=1.0, \mathrm{CHCl}_{3}\right)$.

R)-3-phenylcyclopentanone: Prepared according to the general procedure from 3phenylcyclopent-2-enone (200 $\mathrm{mg}, 1.26 \mathrm{mmol}$ ) for $8.5 \mathrm{~h}$ to provide the title compound as a light yellow oil (147 mg, 73\% yield, 91\% ee) after purification by flash chromatography on Iatrobeads $^{\circledR}\left(10 \% \mathrm{Et}_{2} \mathrm{O} /\right.$ benzene $)$ and a final acid wash. The physical data were identical in all respects to those previously reported. ${ }^{15}$ The enantiomeric ratio was determined by GLC using a Hydrodex-B-TBDAc $(50 \mathrm{~m} \times 0.25 \mathrm{~mm})$ column $\left(145^{\circ} \mathrm{C}\right.$ isotherm, $1 \mathrm{~mL} / \mathrm{min}$.); $(S)$ isomer $t_{\mathrm{r}}=$ $56.3 \mathrm{~min}$. and $(R)$ isomer $t_{\mathrm{r}}=61.3 \mathrm{~min} .[\alpha]_{D}^{22}=+83.5^{\circ}\left(\mathrm{c}=1.00, \mathrm{CHCl}_{3}\right)$.

(R)-methyl 3-oxocyclopentanecarboxylate: Prepared according to the general procedure from methyl 3-oxocyclopent-1-enecarboxylate $(200 \mathrm{mg}, 1.43 \mathrm{mmol})$ for $1 \mathrm{~h}$ at $-10{ }^{\circ} \mathrm{C}$ to provide the title compound as a colorless oil (168 mg, 83\% yield, 90\% ee) after purification by flash chromatography on silica gel $(30 \%$ EtOAc/hexane). The physical data were identical in all respects to those previously reported. ${ }^{16}$ The enantiomeric ratio was determined by GLC using a Hydrodex-B-TBDAc $(50 \mathrm{~m} \times 0.25 \mathrm{~mm})$ column $\left(130{ }^{\circ} \mathrm{C}\right.$ isotherm, $1 \mathrm{~mL} / \mathrm{min}$. $) ;(S)$ isomer $t_{\mathrm{r}}=$ 41.9 min. and $(R)$ isomer $t_{\mathrm{r}}=43.5 \mathrm{~min} .[\alpha]_{D}^{22}=+28.0^{\circ}\left(\mathrm{c}=1.00, \mathrm{CHCl}_{3}\right)$.

\footnotetext{
${ }^{14}$ Yanagisawa, A.; Habaue, S.; Yasue, K.; Yamamoto, H. J. Am. Chem. Soc. 1994, 116, 6130. and Moritani, Y.; Appella, D. H.; Jurkauskas, V.; Buchwald, S. L. J. Am. Chem. Soc. 2000, 122, 6797. (reported an optical rotation of $-96^{\circ}$ for the $(S)$ isomer that is $96 \%$ ee)

${ }^{15}$ Gadwood, R. C.; Mallick, I. M.; DeWinter, A. J. J. Org. Chem. 1987, 52, 774. Gomez-Bengoa, E.; Heron, N. M.; Didiuk, M. T.; Luchaco, C. A.; Hoveyda, A. H. J. Am. Chem. Soc. 1998, 120, 7649. and Hashimoto, S.-I.; Watanabe, N.; Ikegami, S. Synlett. 1994, 353.

${ }^{16}$ Ranu, B. C.; Dutta, J. Guchhait, S. K. Org. Lett. 2001, 3, 2603. The absolute stereochemistry was assigned by analogy.
} 
(R)-3-acetylcyclopentanone: Prepared according to the general procedure from 3acetylcyclopent-2-enone $(200 \mathrm{mg}, 1.61 \mathrm{mmol})$ for $1 \mathrm{~h}$ at $-10{ }^{\circ} \mathrm{C}$ to provide the title compound as a colorless oil (158 mg, 78\% yield, 91\% ee) after purification by flash chromatography on silica gel (50\% EtOAc/hexane). The physical data were identical in all respects to those previously reported. ${ }^{17}$ The enantiomeric ratio was determined by GLC using a Hydrodex-B-TBDAc (50 m $\times 0.25 \mathrm{~mm})$ column $\left(145^{\circ} \mathrm{C}\right.$ isotherm, $1 \mathrm{~mL} / \mathrm{min}$. $) ;(S)$ isomer $t_{\mathrm{r}}=52.0 \mathrm{~min}$. and $(R)$ isomer $t_{\mathrm{r}}=$ $53.3 \min .[\alpha]_{D}^{22}=+56.3^{\circ}\left(\mathrm{c}=1.0, \mathrm{CHCl}_{3}\right)$.

(R)-3-butylcyclohexanone: Prepared according to the general procedure from 3butylcyclohexen-2-one $(200 \mathrm{mg}, 1.31 \mathrm{mmol})$ for $25 \mathrm{~h}$ to provide the title compound as a colorless oil (165 mg, 82\% yield, 90\% ee) after purification by flash chromatography on silica gel $\left(5 \% \mathrm{Et}_{2} \mathrm{O} /\right.$ pentane). The physical data were identical in all respects to those previously reported. ${ }^{18}$ The enantiomeric ratio was determined by GLC using a Hydrodex-B-TBDAc (50 m $\times 0.25 \mathrm{~mm})$ column $\left(150{ }^{\circ} \mathrm{C}\right.$ isotherm, $1 \mathrm{~mL} / \mathrm{min}$. $) ;(S)$ isomer $t_{\mathrm{r}}=37.0 \mathrm{~min}$. and $(R)$ isomer $t_{\mathrm{r}}=$ $36.0 \min .[\alpha]_{D}^{22}=+12.2^{\circ}\left(\mathrm{c}=1.00, \mathrm{CHCl}_{3}\right)$.

(R)-3-cyclohexylcyclohexanone: Prepared according to the general procedure from 3cyclohexylcyclohexen-2-one $(85 \mathrm{mg}, 0.478 \mathrm{mmol})$ for $24 \mathrm{~h}$ to provide the title compound as a colorless oil (61 mg, 71\% yield, $88 \%$ ee) after purification by flash chromatography on silica gel (5\% $\mathrm{Et}_{2} \mathrm{O} /$ pentane). The enantiomeric ratio was determined by GLC using a Hydrodex-BTBDAc $(50 \mathrm{~m} \times 0.25 \mathrm{~mm})$ column $\left(110{ }^{\circ} \mathrm{C}\right.$ isotherm, $1 \mathrm{~mL} / \mathrm{min}$. $) ;(S)$ isomer $t_{\mathrm{r}}=73.5 \mathrm{~min}$. and $(R)$ isomer $t_{\mathrm{r}}=65.2 \mathrm{~min}$. IR (film) 2924, 2853, 1715, 1449, 14223, 1346, 1317, 1263, 1225, 1101, 1056, 982, 892, $866 \mathrm{~cm}^{-1} ;{ }^{1} \mathrm{H}$ NMR (300 MHz, $\left.\mathrm{CDCl}_{3}\right) \delta 2.44-2.21$ (m, 3H), 2.16 - 2.04 $(\mathrm{m}, 2 \mathrm{H}), 1.93-1.85(\mathrm{~m}, 1 \mathrm{H}), 1.80-1.54(\mathrm{~m}, 8 \mathrm{H}), 1.47-1.33(\mathrm{~m}, 1 \mathrm{H}), 1.32-1.11(\mathrm{~m}, 3 \mathrm{H})$, $1.08-0.92(\mathrm{~m}, 2 \mathrm{H}) ;{ }^{13} \mathrm{C}$ NMR $\left(75 \mathrm{MHz}, \mathrm{CDCl}_{3}\right) \_212.9,45.6,44.7,42.7,41.6,30.0,29.9$, 28.4, 26.6, 26.59, 25.54, 25.6; HRMS $\left(E I^{+}\right)$exact mass calculated for $[\mathrm{M}]^{+}\left(\mathrm{C}_{12} \mathrm{H}_{20} \mathrm{O}\right)$ requires $\mathrm{m} / z$ 180.1514, found $m / z 180.1508 ;[\alpha]_{D}^{22}=+11.9^{\circ}\left(\mathrm{c}=1.05, \mathrm{CHCl}_{3}\right)$.

\footnotetext{
${ }^{17}$ Monte, W. T.; Baizer, M. M.; Little, R. D. J. Org. Chem. 1983, 48, 803. (racemic product, no optical rotation)
} 
$(\boldsymbol{R})-3,3,5$-trimethylcyclohexanone: Prepared according to the general procedure from isophorone (200 mg, $1.45 \mathrm{mmol}$ ) for $48 \mathrm{~h}$ to provide the title compound as a colorless oil (134 $\mathrm{mg}, 66 \%$ yield, $98 \%$ ee) after purification by flash chromatography on silica gel (5\% $\mathrm{Et}_{2} \mathrm{O} /$ pentane). The physical data were identical in all respects to those previously reported. ${ }^{19}$ The enantiomeric ratio was determined by GLC using a Hydrodex-B-TBDAc $(50 \mathrm{~m} \times 0.25 \mathrm{~mm})$ column $\left(110^{\circ} \mathrm{C}\right.$ isotherm, $1 \mathrm{~mL} / \mathrm{min}$.); $(S)$ isomer $t_{\mathrm{r}}=11.8 \mathrm{~min}$. and $(R)$ isomer $t_{\mathrm{r}}=12.4 \mathrm{~min}$. $[\alpha]_{D}^{22}=-18.7^{\circ}\left(\mathrm{c}=1.03, \mathrm{CHCl}_{3}\right)$.

(R)-3-butylcycloheptanone: Prepared according to the general procedure from 3butylcyclohept-2-enone $(200 \mathrm{mg}, 1.20 \mathrm{mmol})$ for $9 \mathrm{~h}$ to provide the title compound as a light yellow oil (141 mg, 70\% yield, 92\% ee) after purification by flash chromatography on silica gel (10\% $\mathrm{Et}_{2} \mathrm{O} /$ pentane) and a final acid wash. The physical data were identical in all respects to those previously reported. ${ }^{20}$ The enantiomeric ratio was determined by GLC using a HydrodexB-TBDAc $(50 \mathrm{~m} \times 0.25 \mathrm{~mm})$ column $\left(105^{\circ} \mathrm{C}\right.$ isotherm, $1 \mathrm{~mL} / \mathrm{min}$. $) ;(S)$ isomer $t_{\mathrm{r}}=100.6 \mathrm{~min}$. and $(R)$ isomer $t_{\mathrm{r}}=102.7 \mathrm{~min} .[\alpha]_{D}^{22}=+38.5^{\circ}\left(\mathrm{c}=1.05, \mathrm{CHCl}_{3}\right)$.

\footnotetext{
${ }^{18}$ Jones, P.; Reddy, C. K.; Knowche, P. Tetrahedron 1998, 54, 1471. and Moritani, Y.; Appella, D. H.; Jurkauskas, V.; Buchwald, S. L. J. Am. Chem. Soc. 2000, 122, 6797. (reported a rotation of $-17^{\circ}$ for the (S)-enantiomer that is $87 \%$ ee)

${ }^{19}$ Allinger, N. L.; Riew, C. K. J. Org. Chem. 1975, 40, 1316. (reported a rotation of $+20.3^{\circ}$ for the (S)-enantiomer that is $75 \%$ ee)

${ }^{20}$ Strangeland, E. L.; Sammakia, T. Tetrahedron 1997, 53, 16503. (reported a rotation of $+31.4{ }^{\circ}$ for a product that is $92 \%$ ee)
} 


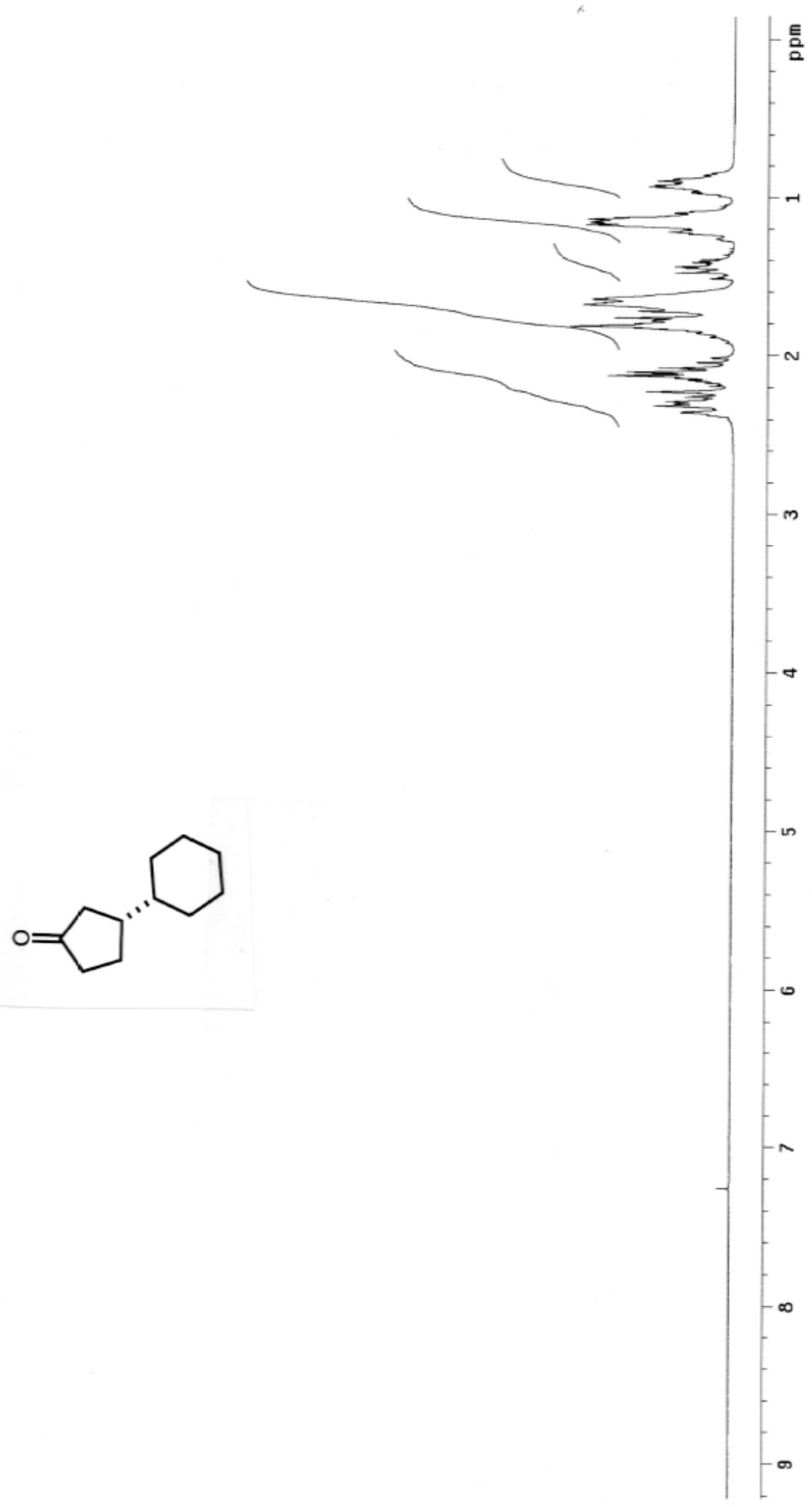




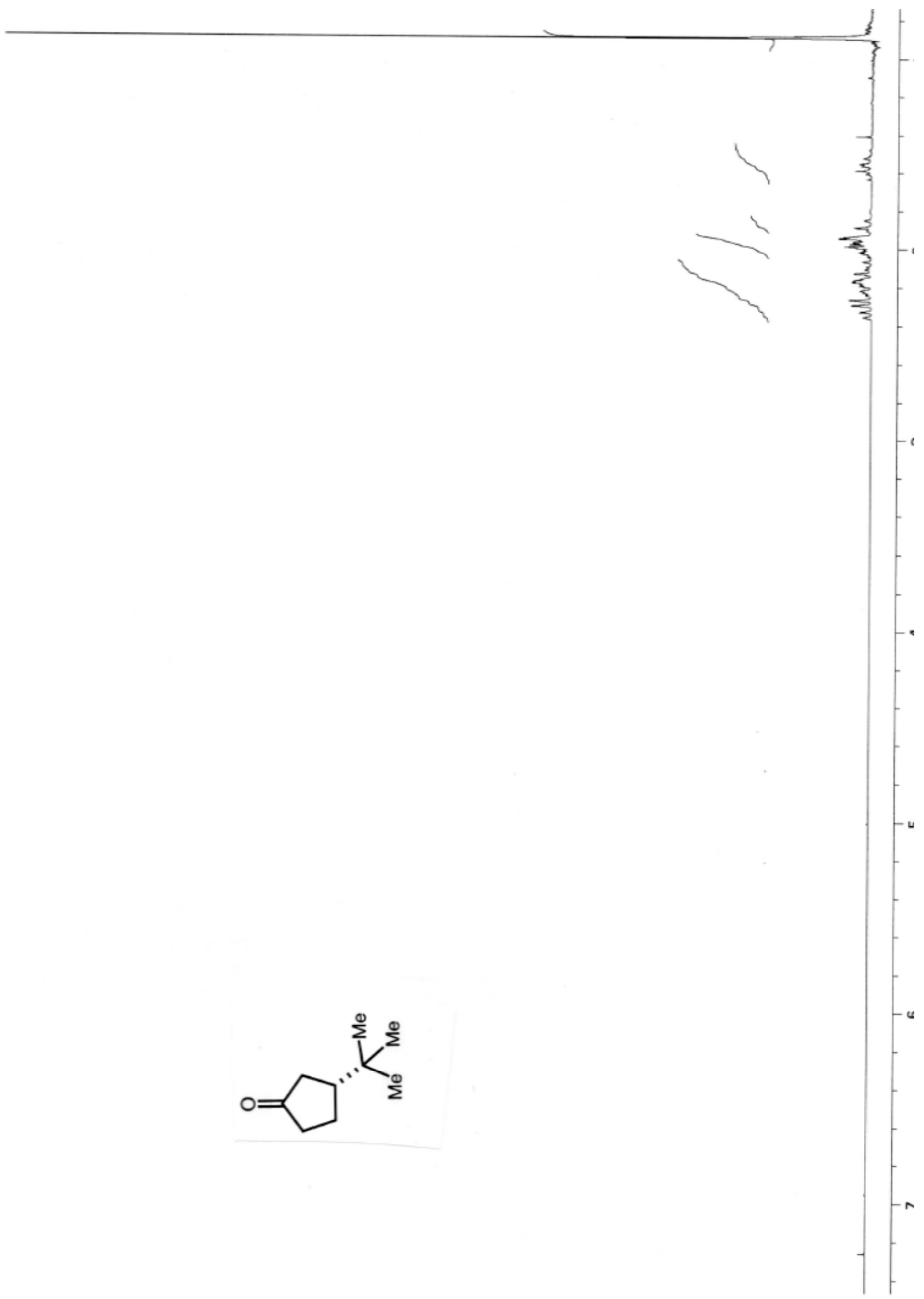




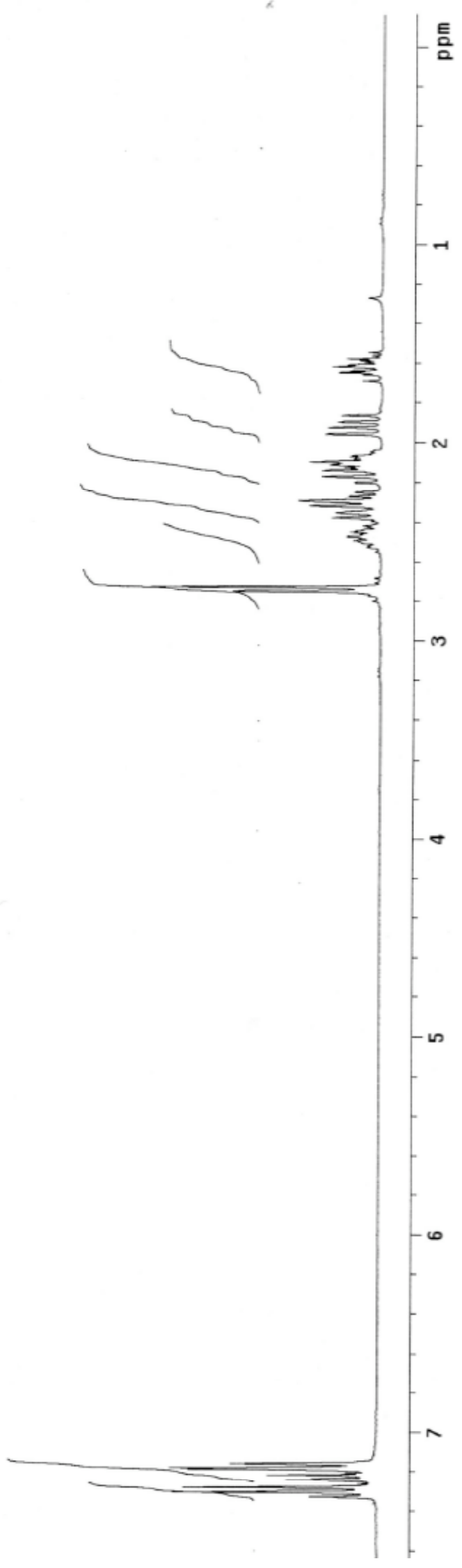



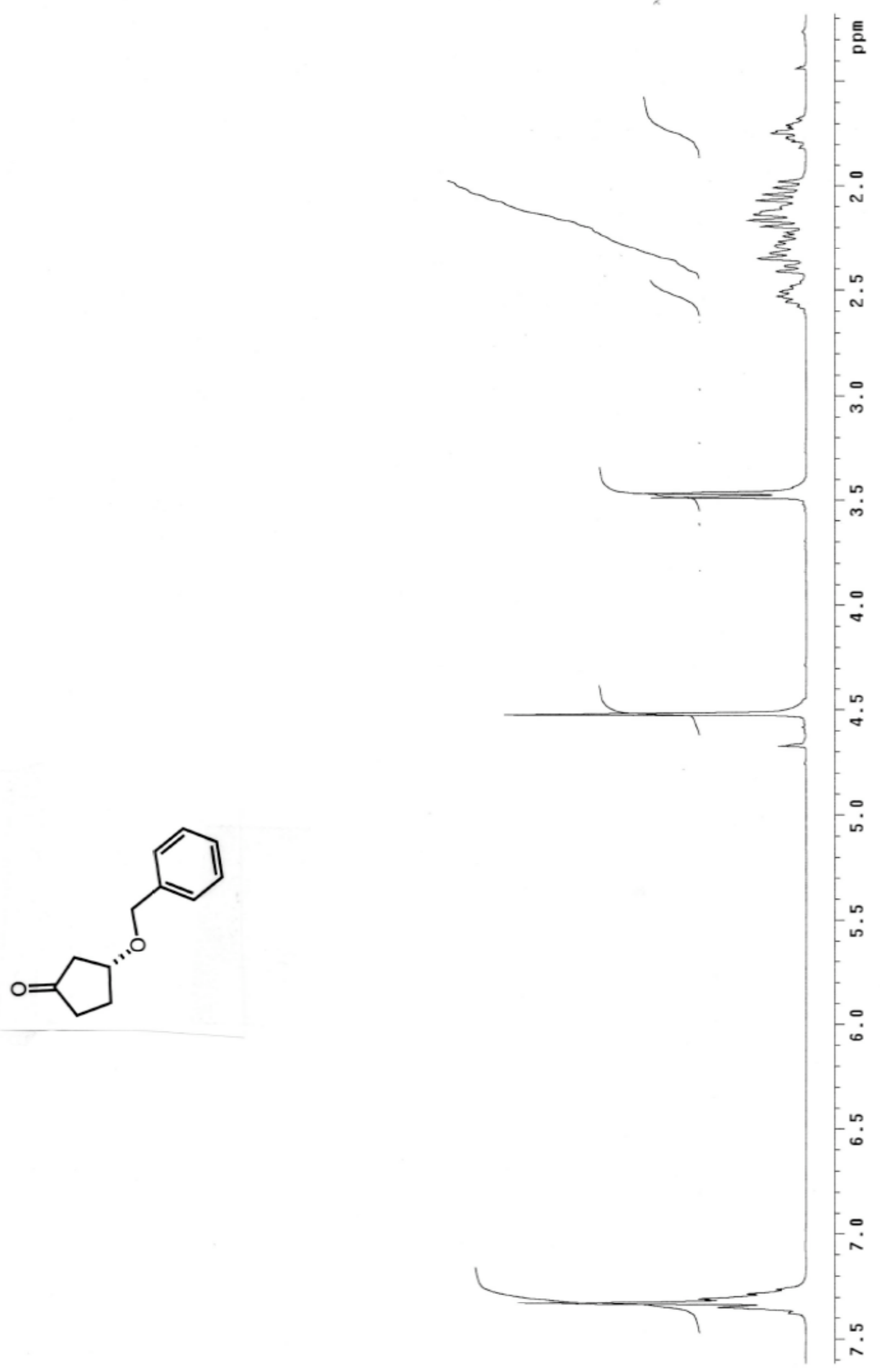


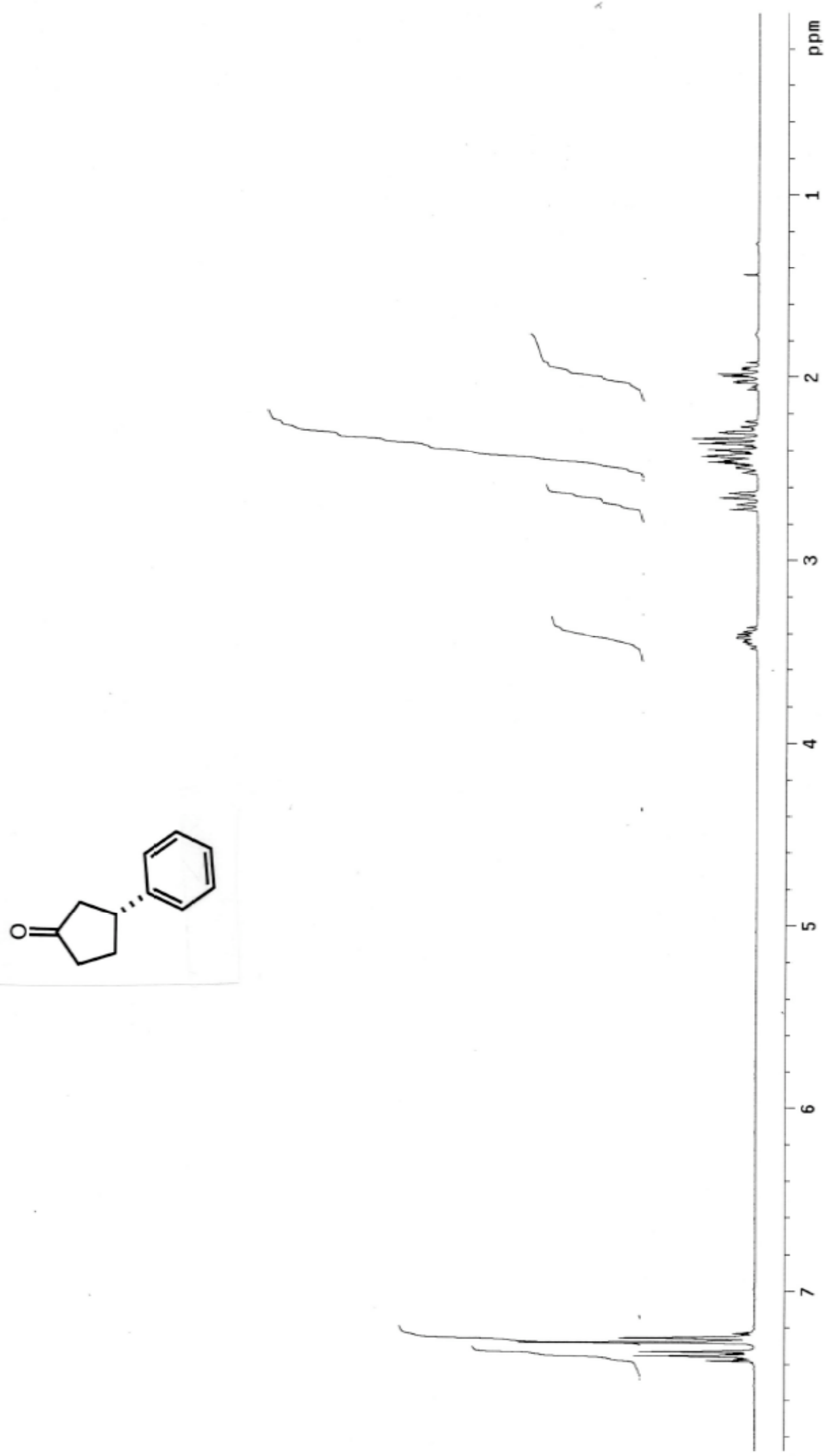




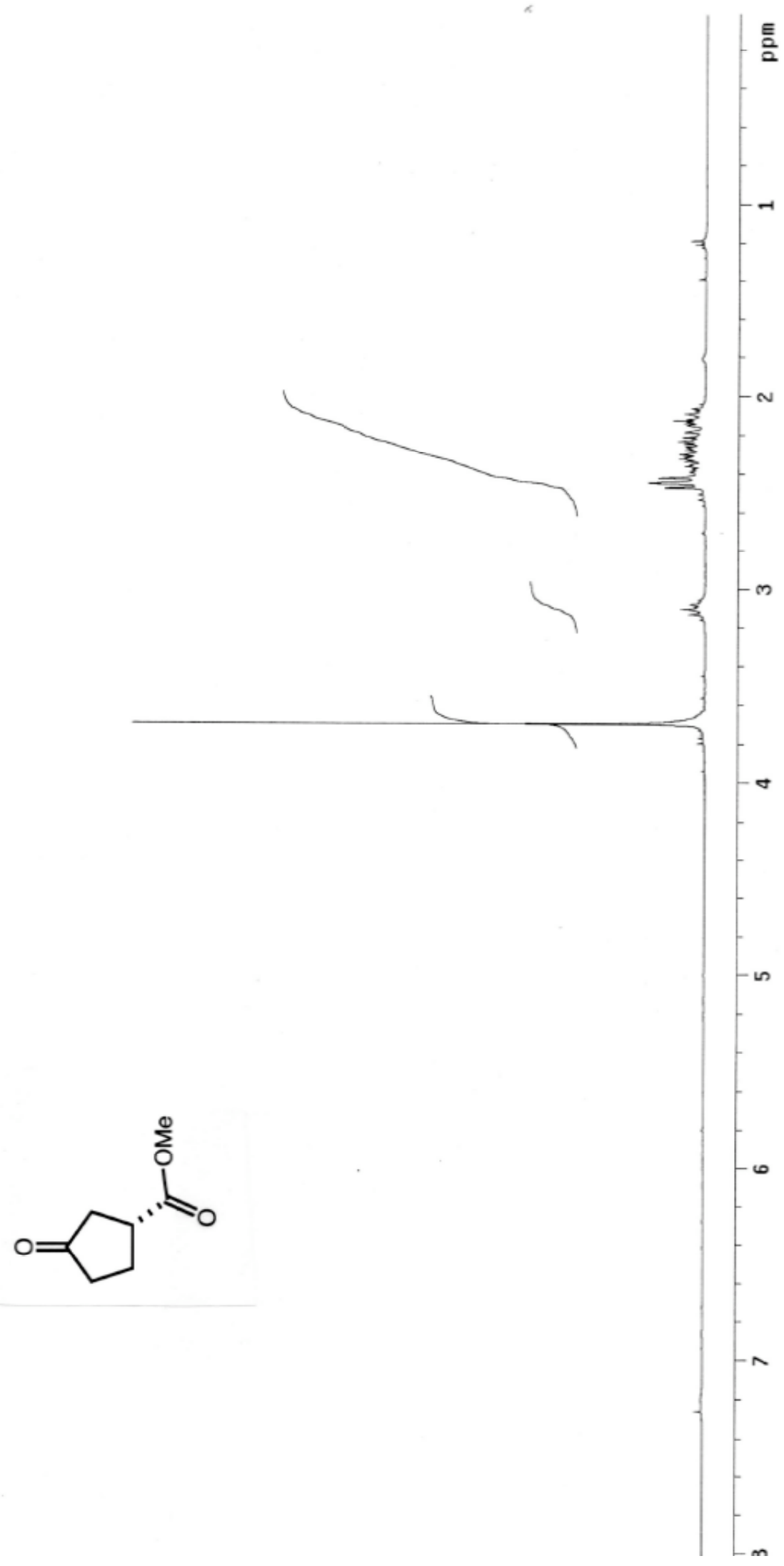




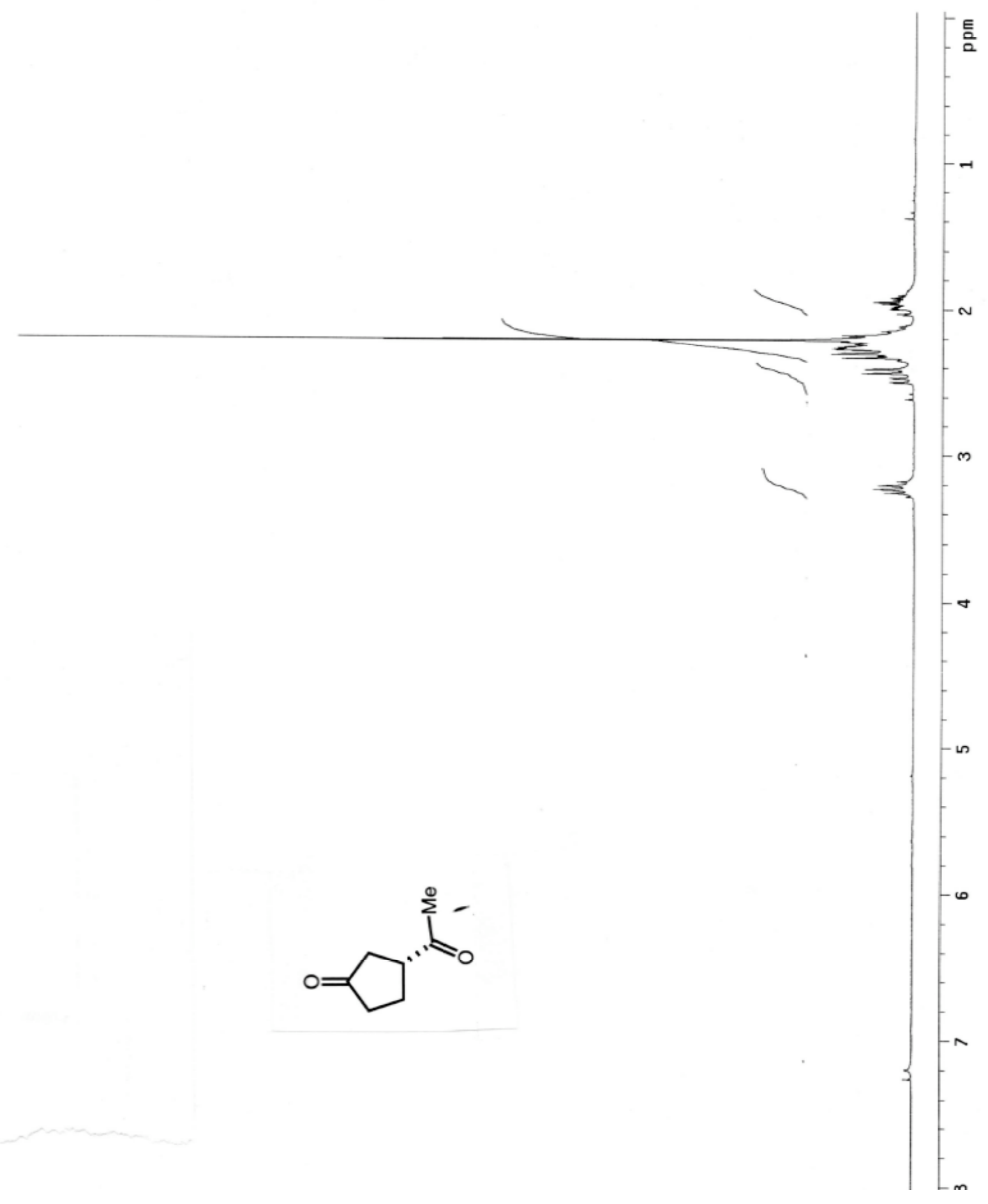




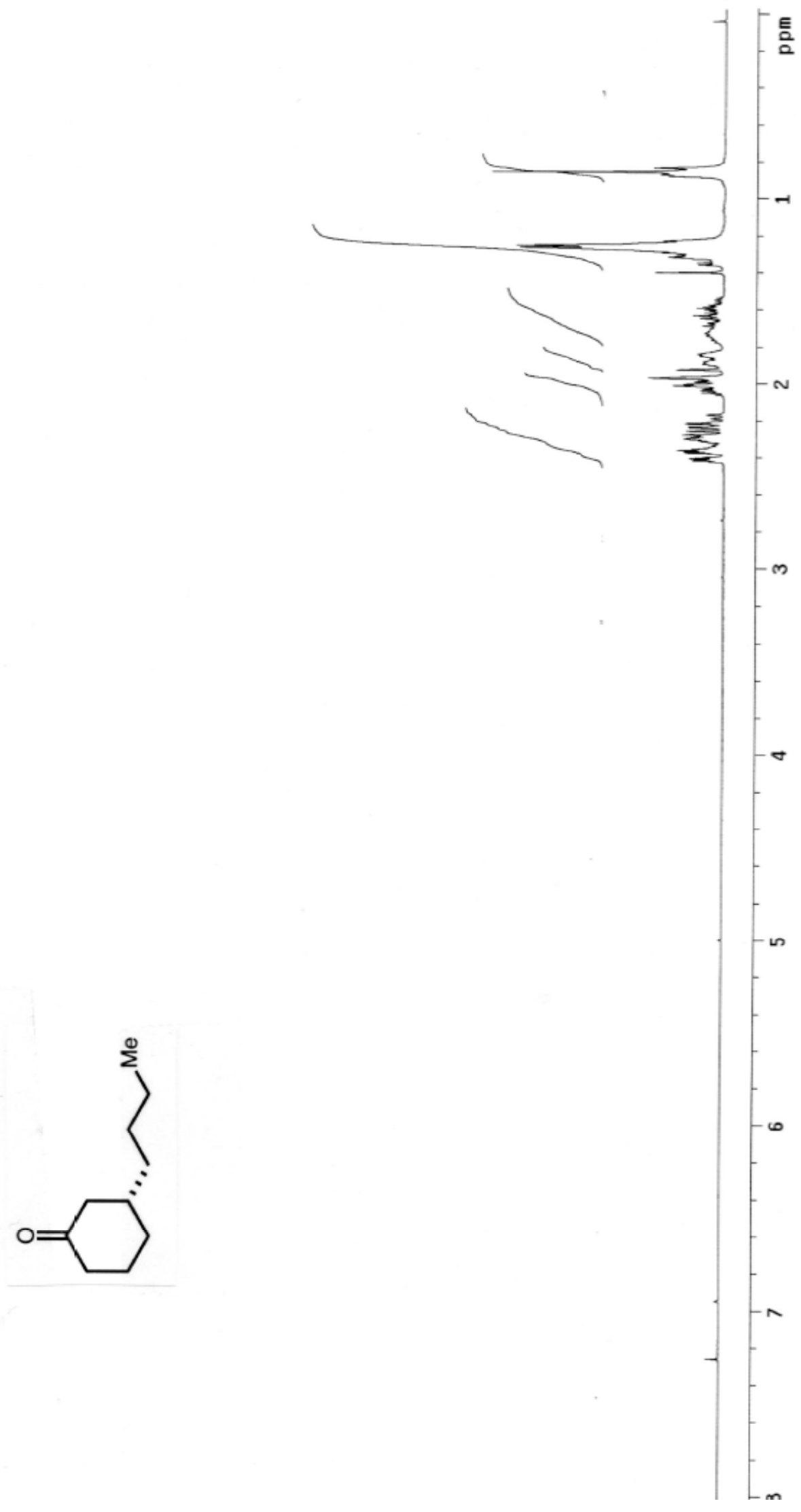



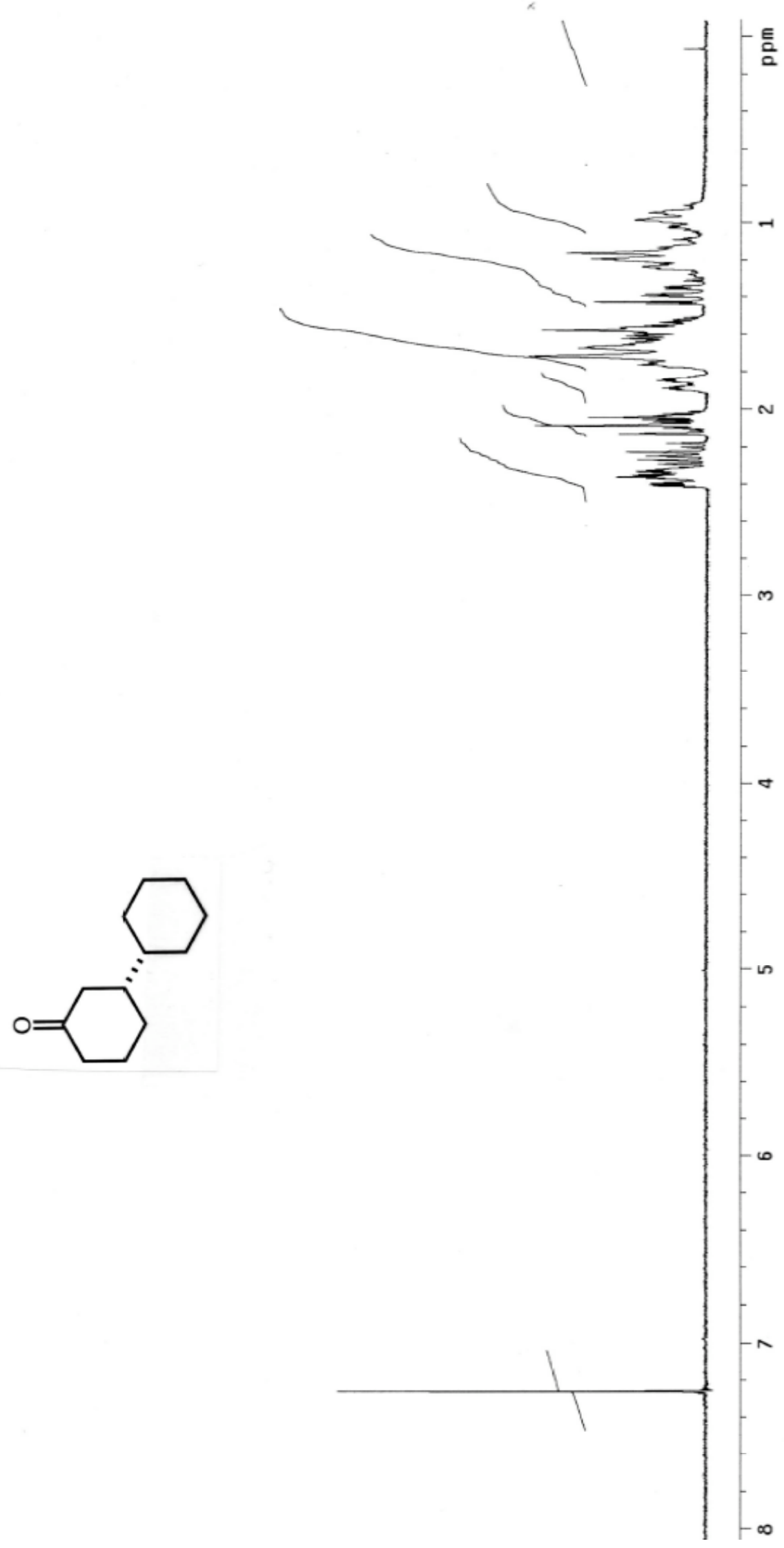


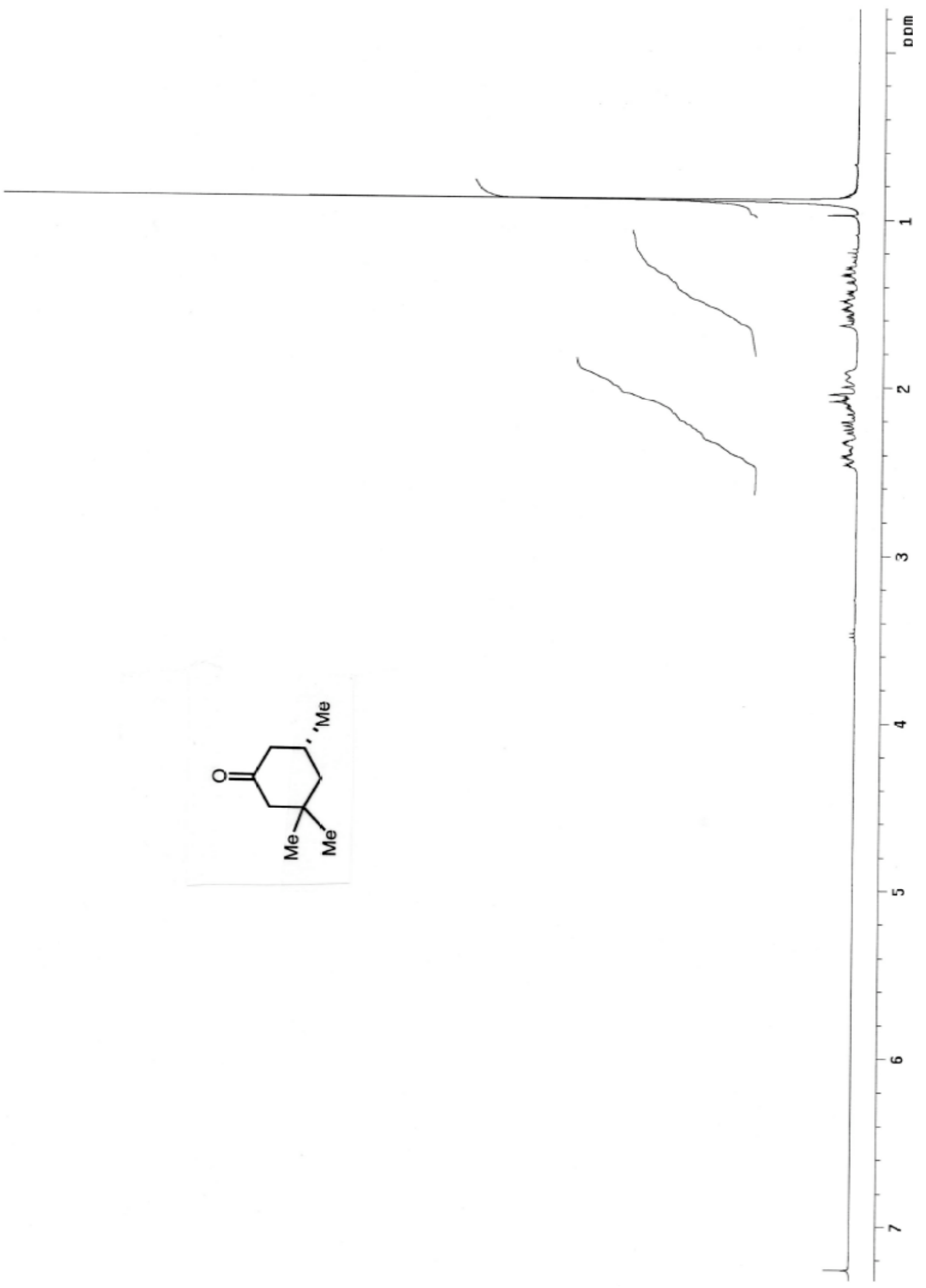




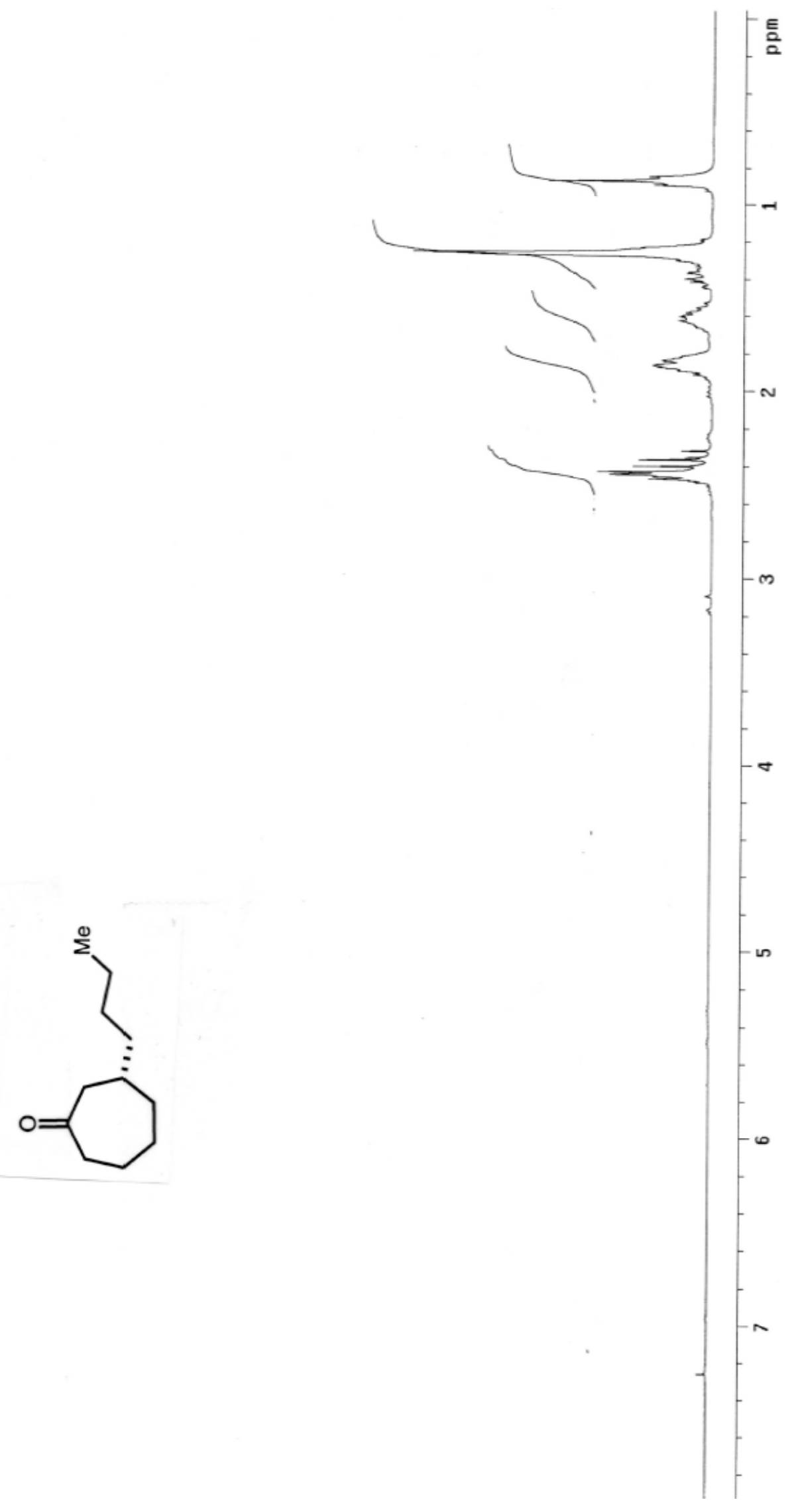

